\title{
Does Luck Exist in Medicine?
}

\author{
Rahul Goel
}

\section{Abstract}

The role of luck in medical care has been acknowledged since times immemorial. Yet with more and more emphasis on evidence based medicine we tend to underplay it. This article provides many examples of how luck has been and always will be relevant in practice of medicine in the world. Keywords: Karma, Luck, Medicine.

Journal of Medical Academics (2019): 10.5005/jp-journals-10070-0028

"One sometimes finds what one is not looking for"-Sir Alexander Fleming

Fortuna (the Roman goddess of good fortune) or "Lady Luck" (as we lovingly call her) has perplexed and fascinated people throughout the ages (Fig. 1). No deed can be considered to have been done without a reasonable amount of luck. Whether its going up in space or diving to the depths of the oceans, luck has its fair share to play. How could it be possible that some people who encounter severe cataclysmic events escape unscratched, whereas the person right next to them dies a gruesome death? It has to be luck, right? Nothing else can explain it. Indeed, in this scientific world, where every statement has to have objectivity, the ideas surrounding luck persist despite their abstract basis.

Before the advent of modern medicine, diseases were considered to have been caused by "evil spirits" or "dark spells" on unfortunate people. ' With time, it became clear that it was not so. Everything had causality and nothing happened on its own. There was nothing called luck or chance. Doctors and scientists toiled in their labs to prove or disprove theories using scientific rationale. The role of the "unknown" undoubtedly went down.

But how can we explain the discovery of the first antibiotic "Penicillin" when Fleming happened to notice that Penicillium fungi growing on agar plates would not allow bacterial colonies to proliferate near it (Fig. 2)? ${ }^{2}$ This chance discovery happened right in time as it was put to good use during World War II and ended up

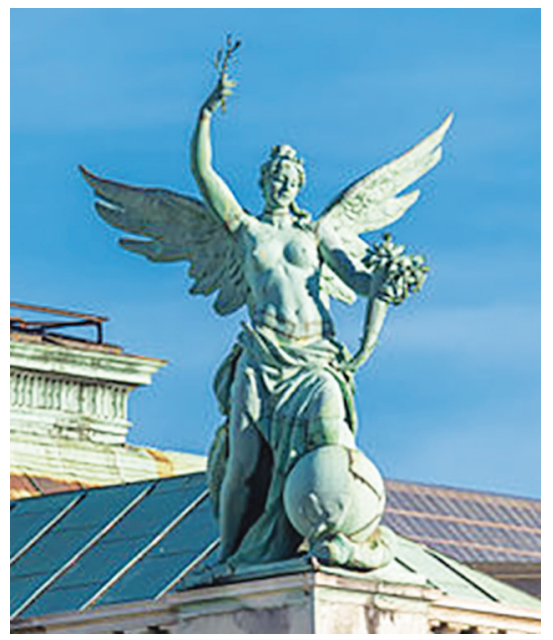

Fig. 1: Sculpture of Fortuna at Vienna (Public Domain Image)
Department of General Surgery, Armed Forces Medical College, Pune, Maharashtra, India

Corresponding Author: Rahul Goel, Department of General Surgery, Armed Forces Medical College, Pune, Maharashtra, India, Phone: +91 9599591858, e-mail: unknownsince1986@yahoo.co.in

How to cite this article: Goel R. Does Luck Exist in Medicine? J Med Acad 2019;2(1):25-26.

Source of support: Nil

Conflict of interest: None

saving thousands of lives. To this date, various forms of penicillin are used daily to fight off terrible infections. ${ }^{3}$

The development of the Pacemaker is another such story. Initially designed as an oscillator to aid in the recording of tachycardias, a chance misconnection by Greatbatch ended up producing the world's first implantable pacemaker. ${ }^{4}$

Dr. Sones conducted the world's first coronary angiography when he accidently cannulated the coronaries of a patient and injected dye in $1958 .^{5}$

Similar serendipitous slips ended up paving the way toward the discovery of X-rays ${ }^{6}$ and nitrous oxide gas. ${ }^{7}$

In my own experience, I have seen even relatively simple surgeries botched up and some of the most complex operations

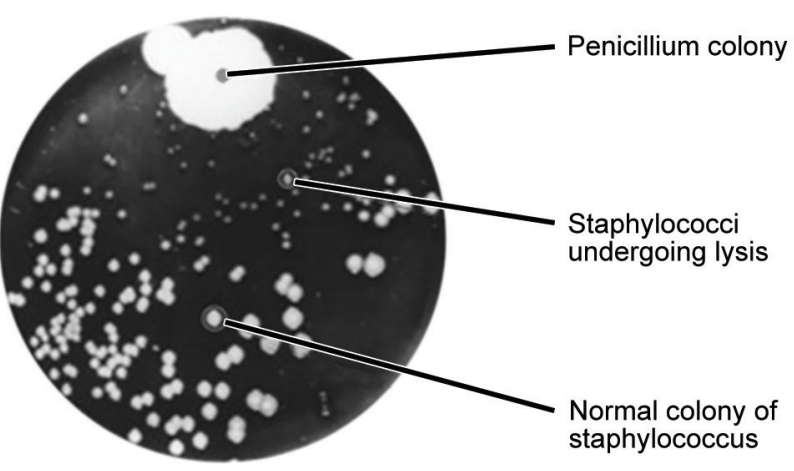

Fig. 2: The original observations of Alexander Fleming in 1928. (Public Domain image)

(O) The Author(s). 2019 Open Access This article is distributed under the terms of the Creative Commons Attribution 4.0 International License (https://creativecommons. org/licenses/by-nc/4.0/), which permits unrestricted use, distribution, and non-commercial reproduction in any medium, provided you give appropriate credit to the original author(s) and the source, provide a link to the Creative Commons license, and indicate if changes were made. The Creative Commons Public Domain Dedication waiver (http://creativecommons.org/publicdomain/zero/1.0/) applies to the data made available in this article, unless otherwise stated. 
gone smoothly. Patients who were otherwise healthy develop a trivial illness and pass away, whereas moribund patients survive. What could explain this aberrant outcome? Luck? Surely the hardest part of any doctor's job is to explain to the patient and himself just why things turned foul when a patient seemed to be doing so well. In our departmental audits, we review the case files, revisit the test results, examine the $X$-rays again, and consult a colleague. But it still does not explain it. Too often the reason for the patient's decline is no reason at all. Except perhaps bad luck.

Luck can mean different things to different people. For some it can be the outcome of spirituality and religion, or Karma. For others, luck is a coin toss, unaffected by reasoning, hence pure randomness. For still others, luck is simply what is yet to be explained in the future.

But for all of us, luck is what we use to explain whatever it is we cannot really explain.

It is a reluctant acknowledgment of how much we do not and cannot know. It is an acceptance of the randomness of fate and the role of chance in how a patient fares. Till the time we have been able to explain each and every event in the Universe, the role of Luck in medicine and life in general will always remain.

\section{References}

1. Goel R. Clinical Examination or Investigational Medicine: The Modern Conundrum. J Med Acad 2018 Dec;1(2):117-118. DOI: 10.5005/ jp-journals-10070-0025.

2. Fleming A. On the Antibacterial Action of Cultures of a Penicillium, with Special Reference to their Use in the Isolation of $B$. influenzae. Br J Exp Pathol 1929;10(3):226.

3. Wennergren $\mathrm{G}$, Lagercrantz $\mathrm{H}$. "One sometimes finds what one is not looking for" (Sir Alexander Fleming): the most important medical discovery of the 20th century. Acta Paediatr 2007 Jan;96(1):141-144. DOI: 10.1111/j.1651-2227.2007.00098.x.

4. Aquilina O. A brief history of cardiac pacing. Images Paediatr Cardiol 2006 Apr;8(2):17-81.

5. Bourassa MG. The history of cardiac catheterization. Can J Cardiol 2005 Oct;21(12):1011-1014.

6. Tubiana M. Wilhelm Conrad Röntgen and the discovery of X-rays. Bull Acad Natl Med 1996 Jan;180(1):97-108.

7. Goerig M, Schulte Am Esch J. History of nitrous oxide - With special reference to its early use in Germany. Best Pract Res Clin Anaesthesiol 2001;15(3):313-338. DOI: 10.1053/bean.2001.0165. 